\title{
Structure of Wild Boar Harvest in the Białowieża Primeval Forest
}

\author{
Lech MIŁKOWSKI \& Jan M. WÓJCIK
}

\begin{abstract}
Miłkowski L. \& Wójcik J. M., 1984: Structure of wild boar harvest in the Białowieża Primeval Forest, Acta theriol., 29, 28: 337-347 [With 3 Tables \& 4 Figs.]

A description is given of the wild boar harvest in the western part of the Białowieża Primeval Forest during the hunting seasons $1970 / 71-1979 / 80$. The average number obtained was 7.6 animals/1000 ha of forest. Piglets formed only a small proportion $(12 \%)$ of the harvest, while the proportion of adult males was high $(35 \%)$. In successive hunting seasons the average weight of disembowelled carcasses was: piglets - 15-31 kg, yearlings - 34-41 kg, sows $53-65 \mathrm{~kg}$ and boars $59-78 \mathrm{~kg}$. A decrease in average carcass weight of yearlings and older wild boars was observed over the ten-year period, the greatest decrease, of about $20 \mathrm{~kg}$, occurring in the adult male class. This phenomenon can be explained by the incorrect harvesting strategy applied to wild boar in the Forest.

[Krzyże 15, 17-230 Białowieża (LM) and Mammals Res. Inst., Polish Acad. Sci., 17-230 Białowieża (JMW), Poland]
\end{abstract}

\section{INTRODUCTION}

Studies on the wild boar population, Sus scrofa Linnaeus, 1758, have been sporadically undertaken in the western part of the Białowieża Primeval Forest, but they were concerned only with a narrow part of the problems. Cabon (1958a) described the course and causes of mass mortality among wild boar in the Białowieża National Park, and also gave a description of the development and growth of the skull in these animals (Caboń, 1958b). In addition Borowski and Miłkowski (1977) assessed the condition and numbers of wild boar after the extremely severe winter of $1969 / 70$.

In the eastern part of the Białowieża Primeval Forest studies have been carried out on variations in numbers, biotope preferences and an analysis made of the food of these animals (Sablina, 1953; Lebedeva, 1956; Kozlo, 1970).

In view of the fact that the wild boar is an important animal from the hunting aspect in the forest, there is a need for long-term studies in order to define variations in numbers and condition of wild boar, and to estimate sex, age and social structure of the population. The present study forms an introduction to some of the above problems, and for 
this purpose analysis was made of the sex and age structure, and also the carcass weight, of wild boar killed during the period 1970-1980 in the western part of the Białowieża Primeval Forest.

\section{STUDY AREA, MATERIAL AND METHODS}

The studies were carried out in the western part of the Białowieża Primeva] Forest over an area of approximately 50.000 ha (excluding the Białowieża National Park). This area comes under the administration of three forestry administration districts: Białowieża, Browsk and Hajnówka, which are in turn divided into 9 hunting areas (Table 1, Fig. 1). In this part of the Forest about $47 \%$ of

Table 1

Forestry administration districts and hunting areas in the western part of the Białowieża Primeval Forest.

\begin{tabular}{|c|c|c|c|}
\hline \multirow{2}{*}{$\begin{array}{l}\text { Forestry } \\
\text { administration } \\
\text { district }\end{array}$} & \multicolumn{2}{|c|}{ Hunting area } & \multirow{2}{*}{$\begin{array}{c}\text { Size of area, } \\
\text { ha }\end{array}$} \\
\hline & Name & Number & \\
\hline Białowieża & $\begin{array}{l}\text { Zwierzyniec } \\
\text { Szkolny } \\
\text { Białowieża }\end{array}$ & $\begin{array}{l}118 \\
129 \\
130\end{array}$ & $\begin{array}{l}5725 \\
1680 \\
4960\end{array}$ \\
\hline Browsk & $\begin{array}{l}\text { Browsk } \\
\text { Ladzka } \\
\text { Narewka }\end{array}$ & $\begin{array}{r}99 \\
101 \\
110\end{array}$ & $\begin{array}{l}8345 \\
6005 \\
6635\end{array}$ \\
\hline \multirow[t]{2}{*}{ Hajnówka } & $\begin{array}{l}\text { Hajnówka } \\
\text { Leśna } \\
\text { Starzyna }\end{array}$ & $\begin{array}{l}119 \\
131 \\
132\end{array}$ & $\begin{array}{l}4665 \\
5540 \\
7485\end{array}$ \\
\hline & Total & & 51050 \\
\hline
\end{tabular}

the area is occupied by deciduous and mixed deciduous forests, and about $38 \%$ by coniferous forest (pine forests), and about $15 \%$ by alder woods (Czerwiński, 1968).

The Primeval Forest forms a favourable habitat for wild boar. Its extensive stretches of wooded land and more or less inaccessible forest (young tree plantations, alder woods) form suitable retreats for animals. During severe winters supplementary feeding is provided, which reduces winter mortality among wild boar to a considerable degree.

Use has been made in this paper of data on wild boar kill over the period of 10 hunting seasons $-1970 / 71$ to $1979 / 80$. These data were obtained from official hunting statistics, and use was made of the following: date and place in which the animal was killed, sex and age of the wild boar shot and weight of the Jisembowelled carcass. The approximate age of the wild boar shot was estimated by the person keeping records, on the basis of external appearance and teeth, dividing individuals into three age classes: piglets (not as yet one year old), yearlings (those over 1 year old but not yet 2 years old), and older animals sows from 2 years of age upwards, and boars over 2 years old. The sex of the animals was determined in all age classes. In addition use was made of carcass 
weight obtained from the game purchasing centre (accuracy of weighing up to $1 \mathrm{~kg})$.

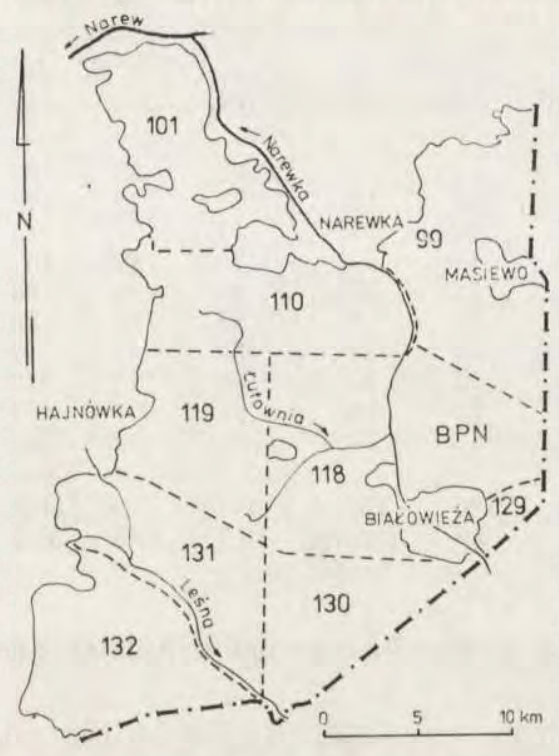

Fig. 1. Division of the western part of the Bialowieża Primeval Forest into hunting areas. Dotted lines indicate boundaries of hunting areas, figures indicate hunting area number, BPN - Białowieża National Park.

\section{RESULTS}

\subsection{Number of Animals Harvested}

During the period of ten successive hunting seasons 1970/71-1979/80 a total of 3400 wild boar were obtained. As only 3160 animals possessed full documentation, only these were taken into consideration in the study, this forming $93 \%$ of all wild boar killed during this period. About $70 \%$ of the animals were shot in the forest, and the remainder in adjacent fields. The largest number of wild boar were shot in winter $(42 \%)$ and summer $(34 \%)$, fewer in autumn $(20 \%)$, and fewest in spring $(4 \%)$.

During the period of these ten hunting seasons the number of wild boar harvested increased by 2.5 times. In the first two seasons the number obtained was about 200 animals, then in successive seasons (1972/73-1976/77 and 1978/79) it was about 300 animals and in 1977/78, $1979 / 80$ the number was almost 500 animals (Table 2). The most distinct rise in the number of wild boar shot in the Forest occurred during the seasons 1972/73 and 1977/78. 
Table 2

Wild boar harvests in the western part of the Białowieża Primeval Forest in hunting seasons $1970 / 71-1979 / 1980$.

\begin{tabular}{|c|c|c|c|c|c|c|c|c|c|}
\hline \multirow{2}{*}{$\begin{array}{l}\text { Hunting } \\
\text { season }\end{array}$} & \multicolumn{3}{|c|}{ Piglets } & \multicolumn{3}{|c|}{ Yearlings } & \multirow{2}{*}{ Sows } & \multirow{2}{*}{ Boars } & \multirow{2}{*}{ Total } \\
\hline & $\sigma^{x} \sigma^{x}$ & 우우 & $\Sigma$ & $\sigma^{x} \sigma^{x}$ & 우우 & $\Sigma$ & & & \\
\hline $1970 / 71$ & 7 & 1 & 8 & 28 & 33 & 61 & 45 & 84 & 198 \\
\hline $1971 / 72$ & 11 & 7 & 18 & 53 & 19 & 72 & 24 & 67 & 181 \\
\hline $1972 / 73$ & 16 & 17 & 33 & 77 & 72 & 149 & 45 & 69 & 296 \\
\hline $1973 / 74$ & 14 & 13 & 27 & 70 & 87 & 157 & 28 & 89 & 301 \\
\hline $1974 / 75$ & 21 & 16 & 37 & 39 & 44 & 83 & 53 & 94 & 267 \\
\hline $1975 / 76$ & 36 & 25 & 61 & 53 & 36 & 89 & 31 & 112 & 293 \\
\hline $1976 / 77$ & 34 & 25 & 59 & 50 & 47 & 97 & 30 & 117 & 303 \\
\hline $1977 / 78$ & 30 & 46 & 76 & 90 & 122 & 212 & 59 & 152 & 499 \\
\hline $1978 / 79$ & 4 & 22 & 26 & 51 & 47 & 98 & 66 & 137 & 327 \\
\hline $1979 / 80$ & 7 & 18 & 25 & 63 & 103 & 166 & 124 & 180 & 495 \\
\hline Total & 180 & 190 & 370 & 574 & 610 & 1184 & 505 & 1101 & 3160 \\
\hline$\%$ & 5.7 & 6.0 & 11.7 & 18.2 & 19.3 & 37.5 & 16.0 & 34.8 & 100.0 \\
\hline
\end{tabular}

\subsection{Spatial Distribution of Animals Shot}

In order to illustrate the intensity of killing wild boar in different hunting areas in the Primeval Forest use has been made of data on shooting for six hunting seasons $1973 / 74-1979 / 80$, calculating the annual

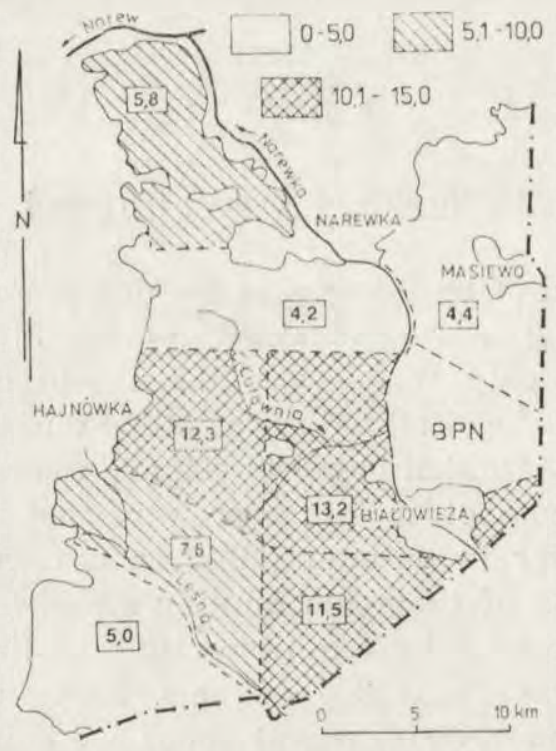

Fig. 2. Average annual wild boar harvest per 1000 ha of forest in the different hunting areas of the Forest, calculated on the basis of data for seasons 1974/75$-1979 / 80$. 
average harvest from 1000 ha of wooded land. During this time the average harvest was 7.6 animals per 1000 ha. Some of the hunting areas were unevenly exploited, those most preferred being immediately adjacent to Białowieża (nos 118, 129 and 130) and Hajnówka (no. 119), where the average annual' harvest came within limits of $11.5-13.2$ animals per 1000 ha. Lower indices of harvest (5.8-7.6 animals per 1000 ha) were obtained for areas nos 101 and 131. The remaining hunting areas were characterized by the lowest average annual harvest $(4.2-5.0$ animals per 1000 ha) (Fig. 2).

\subsection{Sex and Age Structure of Wild Boar Harvest}

During the ten-year period a total of $58.7 \%$ males and $41.3 \%$ females were killed. The sex ratio in young wild boar (piglets and yearlings) did not significantly differ from the ratio $1: 1 \quad\left(\chi^{2}=1.360 ; 0.30>P>0.20\right)$. In the case of older wild boar, about twice as many males as females were shot (Table 2). In successive hunting seasons there was a distinct numerical predominance of males two or more years old over sows of the same age class.

The proportion of wild boar under one year old in the total number killed formed about $12 \%$, with $37 \%$ of yearlings, and the proportion of older animals was almost $51 \%$, males over two years old forming $35 \%$ and females $16 \%$ (Table 2). The proportion of different age classes in

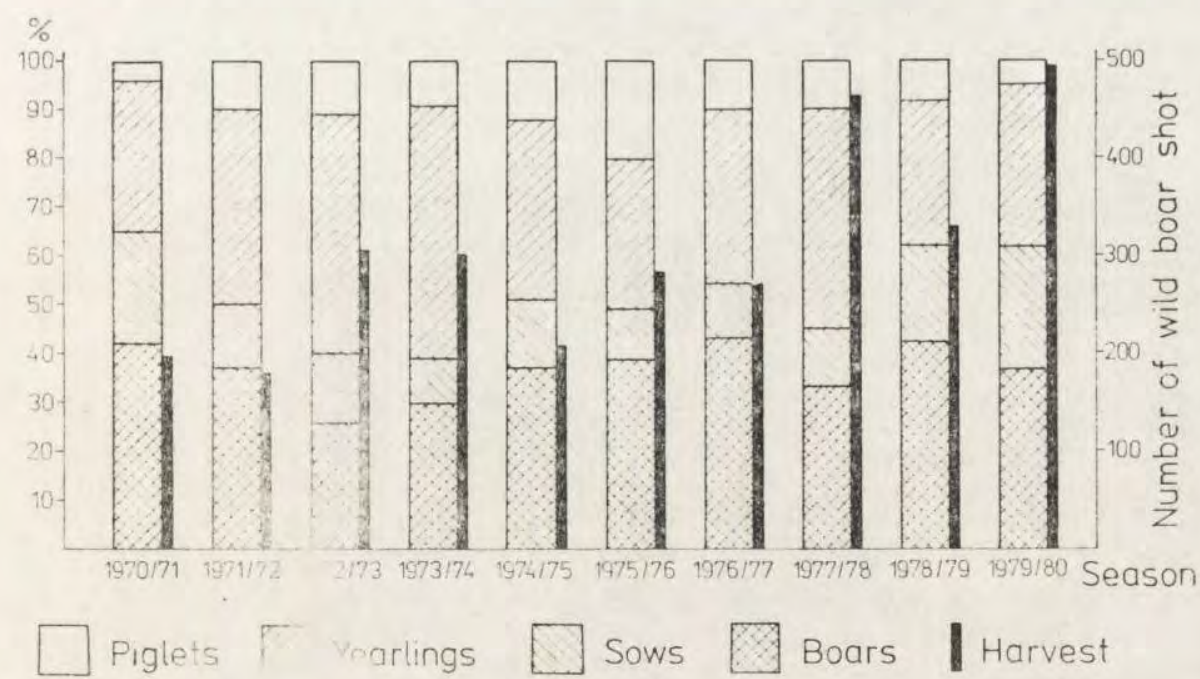

Fig. 3, Proportion of different age classes in the wild boar harvest in seasons 1970/71-1979/80. 
the harvest varied in successive hunting seasons. The percentage of piglets during the first four seasons was from $4-11 \%$, and the highest number of about $27 \%$ was attained in the $1975 / 76$ season, although this dropped again to a few percent in the final seasons. In different hunting seasons the proportion of yearlings varied from $30-52 \%$ of the total number obtained. Older animals formed $40-65 \%$ of the harvest in successive hunting seasons: the percentage of sows was $9-25 \%$, and that of males over 2 years old varied from $25-45 \%$ (Fig. 3 ).

\subsection{Numbers and Population Structure vs. Structure of Harvest}

Counts of wild boar carried out in the spring of 1981 supplied comparative data. The animals were counted by the method of determining the number of animals near feeding places twice, which permitted of approximate assessment of the age structure of the population and, in the case of adult wild boar, of determining sex. Out of 770 counts of wild boar the following were classified: $437(56.7 \%)$ piglets, $149(19.4 \%)$ yearlings, $97(12.6 \%)$ sows and $87(11.3 \%)$ boars. Marked disproportion was found between population structure assessed in this way and the structure of harvest the preceding hunting season 1979/1980. The greatest differences were evident in the case of piglets and males over 2 years old (Fig. 4).

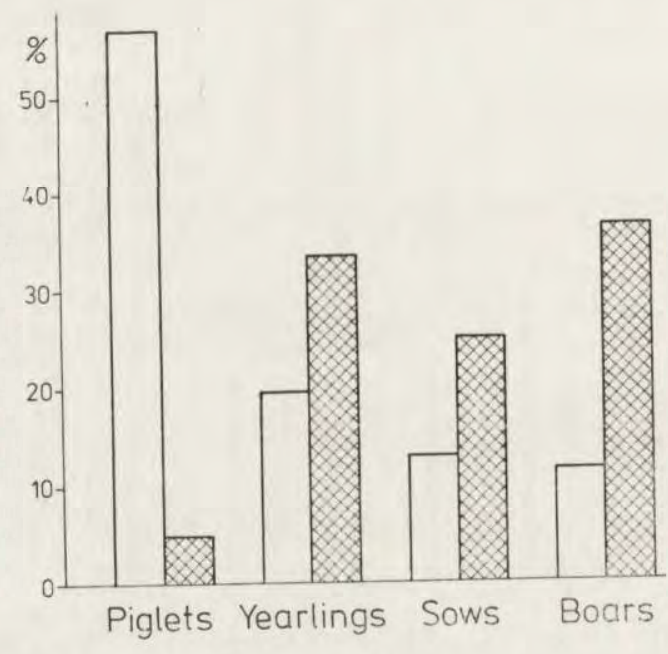

Fig. 4. Comparison of age structure of the wild boar population, on the basis of counts made in March 1981 (clear bars), and the structure of harvest (shaded bars) during the $1979 / 80$ season. 


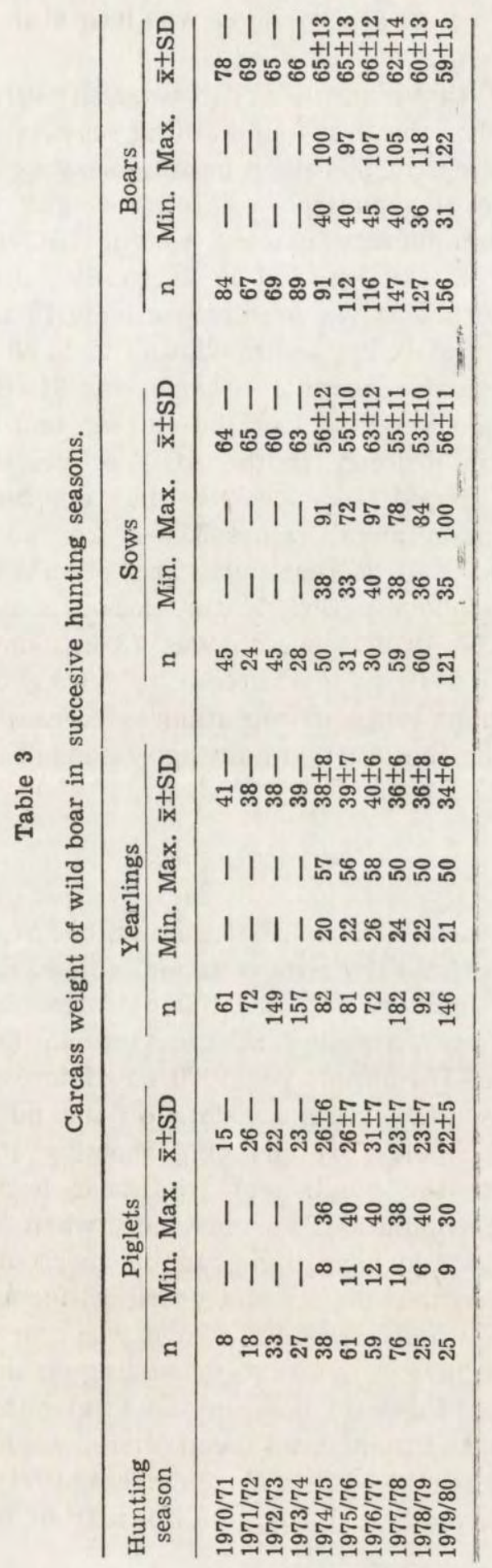




\subsection{Carcass Weight of Wild Boar Shot}

The weights of disembowelled carcasses of 3015 wild boar were -analyzed (Table 3). For the first four hunting seasons only average values were available, whereas in the other hunting seasons it was also possible to obtain the range of variation in carcass weight. In the majority of hunting seasons the average carcass weight (ACW) of piglets came within a range of $22-26 \mathrm{~kg}$, and it was only during the seasons of 1970/71 and 1976/77 that ACWs were respectively 15 and $31 \mathrm{~kg}$. Minimum values varied from 6 to $12 \mathrm{~kg}$, and maximum form $30-40 \mathrm{~kg}$. The ACWs of yearlings in successive hunting seasons was $34-41 \mathrm{~kg}$. The lightest carcasses of yearlings weighted from $20-26 \mathrm{~kg}$, and heaviest $50-58 \mathrm{~kg}$. "There was a distinct decrease in the ACW of yearlings of about $7 \mathrm{~kg}$ over the ten-year period. In successive hunting seasons the ACW of sows was $53-65 \mathrm{~kg}$; minimal values $33-40 \mathrm{~kg}$, maximum values $72-$ $-100 \mathrm{~kg}$. A tendency to decrease was also observed in ACW of sows obtained during the above period. In the class of males over 2 years old the ACW during the $1970 / 71$ season was $78 \mathrm{~kg}$, and during successive years there was a systematic decrease to $59 \mathrm{~kg}$ during the 1979/80 season. The maximum range of variation in carcass weight in this age class occurred during the last two hunting seasons (Table 3).

\section{DISCUSSION}

The material presented shows that the number of wild boar harvested in the Białowieża Primeval Forest was maintained on a low level, with an average of 7.6 animals per 1000 ha of forest. By comparison, the number of wild boar harvested in the German Democratic Republic may be as many as 37 animal's per 1000 ha of forest (Heck \& Raschke, 1980). Although we have no exact data on the numbers of wild boar in the Forest, nevertheless by changing shooting strategy it would be possible to increase the number of wild boar harvested without any great harm to the population. For instance, when 770 wild boar were counted in 1981 it would have been possible to shoot about 700 of these animals, on condition that piglets and yearlings formed over $50 \%$ of this number, and the group of reproducing sows was spared.

Various authors have shown that, depending on the strategy accepted, the proportion of young wild boar in the total number harvested may be from $60-80 \%$ and sometimes even more, while the proportion of :adults does not exceed 10-20\% (Wagenknecht, 1971; Ueckermann, 1978; Erl, 1980; Heck \& Raschke, 1980). It follows from this that far too few 
young wild boar and far too many adult animals (sows and boars over two years old) are killed in the Forest.

The low harvest of wild boar in the youngest age classes, with simulataneously disproportionately high harvest of adults, must have a decided effect on changes in population structure. It causes lowering of average population age and at the same time affects population productivity. In addition a situation of this kind causes weakening of the population since, as Kozlo (1970) states, the susceptibility of young wild boar to disease and parasites is $3-3.5$ times greater than that of adult animals. It is obvious that elimination of mainly piglets and yearlings by shooting is the closest approach to natural selection. The proportion of these age classes in the harvest should be far greater and predominating.

Changes in population structure due to intesive harvesting of the older age classes, cause the formation of large herds of sows with their young, resulting considerable damage to agriculture. The population numbers themselves of wild boar form a factor exerting a lesser influence on the extent of damage done by wild boar in agriculture, since a more important part is played by age and social structures of a population (Mackin, 1970; Andrzejewski \& Jezierski, 1978).

The effect of incorrect shooting strategy is manifested primarily in the decrease in ACW of the wild boar killed. Although it must be remembered that the supply and accessibility of food in a given year significantly affects the condition of wild boar (Sablina, 1955; Lebedeva, 1956; Kozlo, 1970) it would, however, appear certain that so distinct a decrease in the ACW of males over 2 years old (of about $20 \mathrm{~kg}$ ) is to a great extent due to the very great exploitation of this age class. In the case of sows this decrease was smaller $(8 \mathrm{~kg})$, which must be considered as due, among others, to the fact that far fewer sows than adult males were killed during this period. For the sake of comparison, heavier wild boar are killed in the neighbouring north-eastern part of the Soviet Union: disembowelled ACW of males over 2 year old is $72 \mathrm{~kg}$, and sows $66 \mathrm{~kg}$ (Vereshchagin \& Rusakov, 1979). In the German Democratic Republic the ACW of males over 2 years old was as much as $88 \mathrm{~kg}$ (Stubbe et al., 1980).

The facts discussed above prove that the management of the wild boar population carried out in the western part of the Białowieża Primeval Forest is extensive. This situation is not due to ignorance of the problem on the part of the game authorities. The guide lines given by the Central Hunting Council recommend a different harvesting strategy in respect of wild boar, preferring the youngest age class (piglets and yearlings) up to the extent of $80 \%$ of the annual harvest. A similar prin- 
ciple is applied when drawing up annual plans for harvesting wild boar in the Forest. It is, however, a different matter to enforce adherence to these principles in practice. It is necessary to create conditions encouraging hunters to shoot more piglets and yearling wild boar, and to spare the older animals. Special premiums for the purpose, preferring the shooting of young wild boar, would be of assistance. Application of the model preferring piglets and yearling wild boar for shooting is justifield, since it permits of high harvest with a low numerical state of the basic herd. In addition, if this shooting strategy was kept to, it would significantly affect the age structure of the population, a change in the way these animals penetrate the habitat and finally reduction in the amount of damage done in cultivated fields adjacent to wooded land (Andrzejewski \& Jezierski, 1978; Pucek, 1982).

\section{REFERENCES}

1. Andrzejewski R. \& Jezierski W., 1978: Management of a wild boar population and its effects on commercial land. Acta theriol., 23: 309-339.

2. Borowski S. \& Miłkowski L., 1977: Beobachtungen zum Schalenwild in der Bialowiezaheide in den Jahren 1969-1973. Z. Jagdwiss., 23: 169-187.

3. Caboń K., 1958a: Das Massensterben von Wildschweinen im Naturstaatspark von Białowieża im Winter 1955/56. Acta theriol., 2: 71-82.

4. Caboń K., 1958b: Untersuchungen über die Schädelvariabilität des Wildschweines Sus scrofa L, aus Nordostpolen. Acta theriol., 2: 107-140.

5. Czerwiński A., 1968: Baza produkcji leśnej Puszczy. [In: "Park Narodowy w Puszczy Białowieskiej”, Ed. J. B. Faliński]. Państw. Wyd. Roln. i Leśne: 175-198. Warszawa.

6. Erl S., 1980: Erfahrungen mit der Schwarzwildbewirtschaftung in einem Waldgatter. [In: "Schwarzwild - Symposion Giessen", Eds, R. König, R. R. Hofmann]. Enke Verlag, 1: 69-80. Stuttgart.

7. Heck L. \& Raschke G., 1980: Die Wildsauen. Naturgeschichte, Ökologie, Hege und Jagd. Verlag Paul Parey: 1-216. Hamburg, Berlin.

8. Kozlo P. G., 1970: Faktory opredeljajuščie dinamiku čislennosti kabana (Sus scrofa) w Belovežskoj Pušči. Zool. Ž., 49: 422-430.

9. Lebedeva A., 1956: Ekologiceskije osobennosti kabana Belovežskoj Pušči. Uč. Zap. Moskovsk. Gorodsk. Ped. Instituta, 61: 105-271.

10. Mackin R., 1970: Dynamics of damage caused by wild boar to different agricultural crops. Acta theriol., 15: 447-458.

11. Pucek Z., 1982: O gospodarowaniu populacją dzików w Polsce. Stanowisko Komisji Zwierząt Łownych i Rzadkich PAN, Łowiec pol., 4 (639): 22.

12. Sablina T. B., 1955: Kopytnyje Belovežskoj Pušči. Trudy Inst. Morf. Život., 15: $1-191$.

13. Stubbe I., Stubbe M. \& Stubbe W., 1980: Die Körperentwicklung des Schwarzwildes (Sus scrofa L., 1758) im Wildforschungsgebiet Habel. Beitr. Jagd- und Wildforsch., 11: 245-259.

14. Ueckermann E., 1977: Der Schwarzwildabschuss. Verlag Paul Parey: 1-84 Hamburg, Berlin. 
15. Vereshchagin N. K. \& Rusakov O. S., 1979: Kopytnyje Severo-Zapada SSSR. Nauka: 1-309. Leningrad.

16. Wagenknecht E., 1971: Bewirtschaftung unserer Schalenwildbestände. VEB Deutscher Landwirtschaftsverlag: 1-386. Berlin.

Accepted, May 24, 1984.

Lech MIŁKOWSKI i Jan M. WOJCIK

STRUKTURA ODSTRZAEU DZIKOWW W PUSZCZY BIAEOWIESKIEJ

\section{Streszczenie}

Scharakteryzowano pozyskanie dzików na terenie Puszczy Białowieskiej w sezonach łowieckich 1970/71-1979/80. Srednie roczne pozyskanie dzików w Puszczy wyniosło okol 7.6 sztuk z 1000 ha lasu. W poszczególnych obwodach łowieckich średnie roczne pozyskanie zawierało się $\mathrm{w}$ przedziale $4.2-13.2$ sztuk $\mathrm{z} 1000$ ha lasu (Ryc. 2).

Stwierdzono mały udział $(12 \%)$ warchlaków w odstrzale, a duży udział $(35 \%)$ dorosłych samców (Tabela 2, Ryc. 3). Wykazano wyraźne dysproporcje między oszacowaną strukturą populacji a strukturą pozyskania dzików w Puszczy. Największe różnice zaznaczyły się w przypadku warchlaków oraz wycinków i odyńców (Ryc. 4).

W kolejnych sezonach łowieckich średnie ciężary patroszonych tusz warchlaków wynosiły $15-31 \mathrm{~kg}$, przelatków $34-41 \mathrm{~kg}$, loch $53-65 \mathrm{~kg}$ oraz wycinków i odyńców 59-78 kg (Tabela 3). Na przestrzeni 10-ciu lat obserwowano spadek średniego ciężaru patroszonych tusz przelatków i starszych dzików. Największy spadek, około $20 \mathrm{~kg}$, wystąpił w klasie dorosłych samców. Zjawisko to tłumaczy się niewłaściwą strukturą pozyskania dzików w Puszczy Białowieskiej. 